\title{
Spille hverandre gode
}

Forfatterne bak artikkelen Én pasient, to verdener - samhandling mellom sykehjemsleger og sykehusleger i dette nummer av Tidsskriftet (1) konkluderer med at de to gruppene har forskjellig tilnærming til pasientene og lite kommunikasjon seg imellom. Som geriater i sykehus - altså en som ser dette fra den ene siden - har jeg lest artikkelen med både erkjennelse og undring. Er det sant at vi har så forskjellig tilnærming til alvorlig syke eldre? $\mathrm{Og}$ at vi ikke snakker sammen om det? I så fall - hvorfor er det slik?

Blant sykehjemspasientene er det mange skrøpelige eldre med sammensatte medisinske tilstander og betydelig funksjonssvikt. En $ø$ kende andel har alvorlige former for demenssykdom (2). Til tross for tiltak for å forhindre at det skal skje, blir mange akuttinnlagt på sykehus. Tilnærmingen i et sykehus vil være medisinsk. Et solid kunnskapsgrunnlag taler imidlertid for at en bredere vurdering, som inkluderer skrøpelighet og funksjon, gir bedre resultater og også bør benyttes ved akuttinnleggelser (3). Som regel blir det ikke gjennomført en slik tverrfaglig geriatrisk vurdering med vekt på fysiologiske reserver og komorbiditet hvis ikke pasienten kommer til en geriatrisk enhet (4). God informasjon fra sykehjemmet kan imidlertid kanskje erstatte slike vurderinger.

Lite forskning er gjort på forskjeller i tilnærming til alvorlig syke sykehjemspasienter hos ulike legespesialister. Lokale forhold, kultur og tradisjoner har sannsynligvis betydning. Fra mitt ståsted er arbeidet til Romøren og medarbeidere (1) en viktig påminnelse om at vi (sykehuslegene) oftere skal kontakte sykehjemslegene for å drøfte disse pasientene.

I artikkelen kommer det frem at organiseringen av legetjenestene har betydning. Mange innleggelser fra sykehjem til sykehus gjøres av legevaktleger uten kjennskap til pasientene og de føringer som er lagt, for eksempel for hvor intensiv behandlingen skal være. Sykehuslegene meddeler at pasienter ofte kommer med knappe, eller helt uten, innleggelsesskriv. Det blir vanskelig å vurdere behandlingsintensitet, og resultatet kan bli overutredning og overbehandling basert på en oppfatning om at pasienten jo ble innlagt i sykehus og da må så mye som mulig gjøres. Dette er et forbedringsområde der ansvaret ligger i sykehjemstjenesten. Sykehusleger hevder at det er enklere og tar kortere tid å gi informasjon i epikrisen enn å prøve å få tak i sykehjemslegen over telefon. Med den tilnærmingen vil man gå glipp av viktige tilbakemeldinger fra sykehjemslegen og en drøfting av den videre behandlingsplanen. I tillegg vil epikrisekvaliteten bli avgjørende for pasientbehandlingen ved tilbakeføring til sykehjemmet.

Tid som kritisk faktor må vi forholde oss til også i fremtiden. Vi vil ikke få mer tid til å kommuniserer med kolleger på tvers av helsetjenestene. Dermed må vi kommunisere på en tidseffektiv måte. Enda flere møter vil trolig ikke løse problemet. Telefonkonferering blir sett på som en nyttig ordning og et godt møtepunkt for kommunikasjon og bør kanskje brukes mer - og ikke bare ved spørsmål om innleggelse, men også fra sykehuslege til sykehjemslege. Noe av problemet ligger i at det er enklere å få kontakt med vakthavende lege ved et sykehus enn med pasientansvarlig sykehjemslege. Enkle grep som å påføre direktenummeret til sykehjemslegen på henvisningen kan bedre dette. I tillegg vil kanskje økt bruk av kommunikasjonssystemer på legenivå være nyttig. Mitt inntrykk er at elektroniske pleie-og-omsorgs-meldinger (PLO) fungerer godt i kommunikasjonen mellom primærhelsetjenesten og sykehuset og at dette systemet kunne brukes til lege-til-lege-kommunikasjon i større grad. Gjerne også med beskjeden «kan du ringe meg (på nummer xxx xx xxx), så kan vi diskutere dette».

Ulike holdninger har ofte sammenheng med ulikt «språk», ulike diagnostiske metoder og ulik kompetanse. Sykehjemslegene ser pasienten i sitt vanlige element, mens sykehuslegene ser dem i en akutt situasjon der det er vanskelig å vite hvordan de pleier å ha det. På den annen side vil sykehuslegene kunne gjøre mer presis diagnostikk av akutte lidelser og har bedre muligheter for å behandle disse. Begge forhold må tas i betraktning ved beslutninger. Vi trenger forståelse i sykehuset om at opplysninger som kan innhentes fra kollegaen på sykehjemmet, vil kunne fremme en bedre beslutningsprosess (3). Gjennomføring av en systematisk kartlegging av funksjon og kliniske problemer og en forberedende samtale i sykehjemmet vil kunne møte behovet fra sykehuset og gi viktige føringer (5).

Det er ikke vanskelig å slutte seg til den avsluttende kommentaren i artikkelen: «Uttrykket «å spille hverandre gode» kunne kanskje inspirere i dette endringsarbeidet. Sykehjemsleger og sykehusleger kunne åpenbart hatt mer nytte og glede av hverandre - til beste for pasienten.» Jeg foreslår mer bruk av hospiteringsordninger og å invitere hverandre til kunnskapsformidling som ledd i internundervisning.

Anette Hylen Ranhoff

anette.ranhoff@uib.no

Anette Hylen Ranhoff (f. 1956) er seksjonsoverlege i geriatri ved Diakonhjemmet Sykehus, professor i geriatri ved Universitetet i Bergen og seniorforsker ved Folkehelseinstituttet. Hun har lang klinisk erfaring og forskningsinteresse for behandlingen av alvorlig syke gamle i sykehus. Forfatter har fylt ut ICMJE-skjemaet og oppgir ingen interessekonflikter.

\section{Litteratur}

1. Romøren M, Pedersen R, Førde R. En pasient, to verdener - samhandling mellom sykehjemsleger og sykehusleger. Tidsskr Nor Legeforen 2017; 137: 193-7.

2. Helvik AS, Engedal K, Benth JŠ et al. Prevalence and Severity of Dementia in Nursing Home Residents. Dement Geriatr Cogn Disord 2015; 40: 166-77.

3. Conroy SP, Turpin S. New horizons: urgent care for older people with frailty. Age Ageing 2016; 45: 577-84

4. Gladman JR, Conroy SP, Ranhoff AH et al. New horizons in the implementation and research of comprehensive geriatric assessment: knowing, doing and the 'know-do' gap. Age Ageing 2016; 45: 194-200.

5. Beslutningsprosesser ved begrensning av livsforlengende behandling. Revidert 2013. Oslo: Helsedirektoratet, 2009 